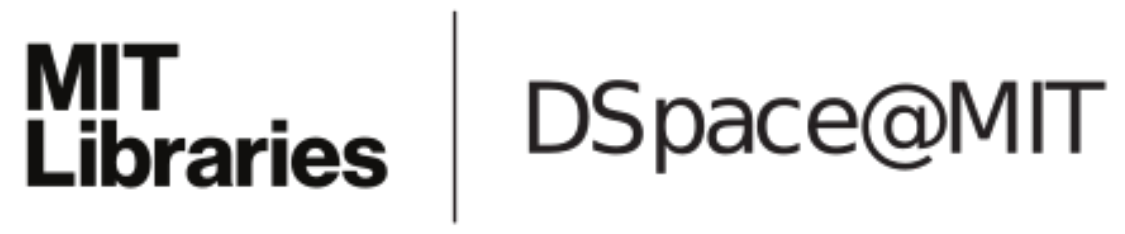

\author{
MIT Open Access Articles
}

Reflecting on Fifty Years of Progress for Women in Science

The MIT Faculty has made this article openly available. Please share how this access benefits you. Your story matters.

Citation: Hopkins, Nancy. "Reflecting on Fifty Years of Progress for Women in Science." DNA and Cell Biology 34, no. 3 (March 2015): 159-161.

As Published: http://dx.doi.org/10.1089/dna.2015.2803

Publisher: Mary Ann Liebert, Inc.

Persistent URL: http://hdl.handle.net/1721.1/96719

Version: Final published version: final published article, as it appeared in a journal, conference proceedings, or other formally published context

Terms of Use: Article is made available in accordance with the publisher's policy and may be subject to US copyright law. Please refer to the publisher's site for terms of use. 


\title{
Reflecting on Fifty Years of Progress for Women in Science
}

\author{
Nancy Hopkins
}

$\mathbf{L}$ IKE YOUNG WOMEN today, 50 years ago I too assumed that gender discrimination in science was a thing of the past. Girls who grew up in America in the Sputnik era, as I did, were encouraged to become scientists. By 1964, when I graduated from college with a major in biology, I thought it entirely possible I'd win a Nobel prize. Why not? Dorothy Hodgkin won one that year. At Harvard, my professors had strongly encouraged me to go to graduate school. When I finished my postdoc in 1973, I was actively recruited to the MIT faculty. What were those feminists complaining about?

I would have understood had I known that 50 years ago it was almost impossible for a woman to get a faculty job in any American research university, and that it would take civil rights legislation in the mid ' 60 s and early ' 70 s to make it possible.

Following is a brief account of how I came slowly to comprehend that gender bias did (and still does) exist in science, and how, starting in 1994, I worked with other women faculty and with the MIT administration to understand and mitigate its effects, with outcomes none of us could have imagined. Progress for women in academic science has been remarkable over the past half century, though equality remains elusive in all universities because of persistent societal, unconscious, and institutional gender biases.

\section{Falling in Love with Science}

I fell in love with science in the spring of 1963, my junior year at Radcliffe College (the girl's division of Harvard then), when I signed up for an introductory biology class taught by James D Watson. I emerged from the first lecture in shock. These molecular biologists were figuring out the secret of life! Forget medicine, philosophy, psychology, or religion; DNA was going to explain the origin of life, the molecular basis of human disease-maybe even human behavior. Watson agreed to let me work in his lab and became my advisor, guru, mentor, advocate, and friend.

The science drew me to Jim's lab every available moment. I lived in a state of euphoric scientific excitement. Jim told me repeatedly I should be a scientist. I knew I couldn't live without this science, but how could I be like these men? Even postdocs had wives who stayed home to care for their children while the men put in 70-hour weeks at the lab. Who would care for my children? I knew I would have to give up science before I had children: in the era before amniocentesis, that meant before the age of 30. So I made a plan: do the most exciting science possible as fast as you can, hope you do a Nobel Prize-winning experiment before the age of 30 , then retire and be a wife and mother.

Jim, unaware of my life plan, insisted I pursue a $\mathrm{PhD}$. I went to Yale, but no one there was working on the only problem I wanted to work on-isolating the repressor and seeing if it bound to specific sequences on DNA to control gene expression. So I dropped out and went back to Harvard where Mark Ptashne was trying to isolate the lambda phage repressor, and I worked as his technician. Less than a year and a half later, the experiment worked. Triumphant, we ran through the halls waving a graph showing the famous proteinDNA binding peak. Dream accomplished! (Although the experiment didn't win a Nobel Prize, and I would not have expected to be included if it had.) I was 24 and might have quit science within a few years had Jim not come to Mark's lab one day and said, "OK, Nancy, you've had your fun, now you have to get a PhD." The next day I was enrolled in graduate school at Harvard. As luck would have it, I needed the $\mathrm{PhD}$ after all, because when I was 30, instead of having children, I got divorced and took a job on the MIT faculty.

Given such an auspicious start, no wonder I didn't see any gender discrimination in science. But looking back, it's hard to understand how I could have been quite so slow to recognize that a profession in which half the population can't participate equally and also have children is by definition discriminatory. I saw the family-work problem as a biological one-a woman's choice, unfixable. It would be years before my colleague, Professor Lotte Bailyn, helped me see that the way science careers and institutions are structured is an artificial and hence changeable system designed by men, for men, in an era when men had full-time wives to care for their families.

So taboo was this subject for women striving to be top scientists that more than three decades passed before I sat down with other women faculty and the MIT administration to discuss it. Though MIT had a family leave policy for faculty at the time, women were afraid to use it because of the stigma attached to it. Men took leave without a qualm, often using the extra time to do more research or start a company.

This problem turned out to be easier to address than we had thought, by new family leave policies arrived at in 2002

Department of Biology, Massachusetts Institute of Technology, Cambridge, Massachusetts. 
after discussions among all women faculty, Deans, department heads, and the Provost under the administration of MIT President Vest, and by a large new day-care center in the middle of campus. Soon, taking family leave and getting tenure became routine for women. One can only wonder what took so long. Even 50 years ago, it should have been obvious that if society wanted more women scientists on university faculties, it would have to provide on-site day care, family leave, tenure extensions for bearing a child, coverage for funding gaps, and sufficiently high salaries to help replace a traditional wife at home. It had to ensure that having children was not a "woman's problem" but an issue affecting women and men equally. Even today, despite enormous progress, more changes to the structure of the profession are needed, by both universities and funding agencies, if more women and men are to achieve their full professional potential while being equal partners in the home (Mason et al., 2013).

\section{Recognizing Unconscious Gender Bias and Taking Collective Action at MIT}

In sharp contrast to the above problem, 50 years ago, we didn't know enough about gender discrimination to be able to mitigate its effects. We thought Title VII laws and regulations in the mid-1960s and 1970s that made it illegal to deny women jobs in America were all that was needed to level the playing field. We were wrong. Today, we know that unconscious (implicit) gender bias, probably more than family-work conflict, explains why progress for women in STEM fields has been so slow (Valian, 1999; Banaji and Greenwald, 2013).

Psychologists discovered unconscious biases, but many professional women scientists came to understand unconscious gender bias on their own. For decades, most suffered it in silence for fear of being labeled a "whiner" or judged "not good enough." I began to understand it as a newly independent junior faculty member, but for years, I attributed any lack of success to my own failings, particularly not being sufficiently aggressive or self-promoting in a highly competitive profession. My response was always to work harder, to try to do a better experiment, on the theory that if you did a Nobel Prize-winning experiment, you wouldn't have to be self-promoting-everyone would have to acknowledge your discovery.

I discovered I was mistaken by watching how other women scientists were treated. I came to see that when women and men made scientific discoveries of equal importance, the man and his discovery were valued more highly than the woman and her discovery. Often, the woman was almost invisible. Incredibly, a woman could even make a Nobel Prize-winning discovery and still not be given credit! No wonder so few women got to the very top. It wasn't for lack of groundbreaking discoveries, but for lack of acknowledgment that they had made them. Men of lesser accomplishment often had more accouterments of success than women who were better scientists and had made more important discoveries.

It was impossible to tell anyone this astonishing discovery. Who would believe you? Science is supposed to be a meritocracy. Even more frustrating was dealing with the daily consequences of women's undervaluation-smaller labs, fewer resources for research. Some people think that women don't ask for enough, but I learned that when they asked for resources, they didn't get them. When women inquired about their salaries in the mid-1990s, some men said they shouldn't see the data, since it would only depress them to know what the men in power really thought of them.

In 1994, as has been reported in detail before (Bailyn, 2011; Hopkins, 2011), tenured women faculty in the six departments of science at MIT began to discuss these issues. Almost all had either experienced or seen the phenomenon of unconscious bias, but they had no name for it, often doubting their own perception of such an astonishing truth. In 1995, they asked the Dean of Science to establish a committee to study the manifestations and impact of this invisible bias. He agreed, and when their report was in his hands, he promptly addressed and corrected inequities of resources and rewards that could be fixed easily.

In 1999, a summary of the committee's findings and the Dean's response was published in the MIT faculty newsletter (Committee on Women Faculty in the School of Science, MIT, 1999) and reported on the front pages of The Boston Globe and The New York Times (Baily, 2011; Hopkins, 2011). The response from women all over the country, and soon the world, was overwhelming. Overnight, we learned that the undervaluation of women in academic science and other fields was widespread in universities, labs, and companies. Helping finally to end women scientists' silence was the fact that the MIT women who had spoken out were such successful scientists. They had been tenured at the same rate as men, and today, of the 16 women faculty who brought the matter to MIT's attention, four have won the U.S. National Medal of Science and 11 are members of the National Academy of Science or Engineering. Anyone who would suggest that these women weren't good enough would simply look like a fool, as well as a bigot.

\section{Extraordinary Progress for Women in Science}

With the detailed knowledge of the barriers that so many women faculty in science and engineering encounter, then President of MIT, Charles Vest, set out to make institutional changes to fix the problems. The effort was monumental, involving the Provost, Deans, and many senior women and men faculty. It required novel administrative structures, the use of superb institutional data, and the commitment of successive administrations. Progress was remarkable and changed the lives of many women faculty (Hopkins, 2007). We learned some important lessons.

- Time alone does not change things-deliberate action by powerful administrators changes institutions.

- Progress requires the commitment of the head of the institution.

- It is essential to bring women into powerful leadership positions, including responsibility for this issue.

- Superb data are essential to track hiring and the equitable distribution of resources, rewards, and compensation over time. Mechanisms are required for swift correction of biased hiring and other inequities.

- To increase the number of women faculty requires oversight at a level above individual departments because of the slow rate of faculty turnover and the small number of faculty hired each year.

- If you stop tracking data and preventing inequities in hiring or distribution of resources and compensations, progress stops and may even retrogress. 
A 2011 survey of all female STEM faculty at MIT revealed that women today feel enormously privileged to be there, while recognizing that problems remain (Committees on Women Faculty in the Schools of Science and Engineering, MIT, 2011) (see below). As for numbers, the percent of women faculty in science and engineering departments at MIT today equals the percent of women in the applicant pools: thus, there is no bias in hiring. However, only $19 \%$ of the science faculty and $17 \%$ of the engineering faculty are women. There are two reasons: the small number of women getting PhDs in some fields, and leaks in the pipeline between $\mathrm{PhD}$ and faculty applicant pools in others. Even without leaks, women would comprise at most some $30 \%$ of the MIT science faculty and $20 \%$ of the engineering faculty because of the small percent of women getting PhDs in physics, computer science, math, and mechanical engineering.

As for the "leaky pipeline" between PhD and faculty, it is particularly striking in fields with the most female $\mathrm{PhDs}$, such as biology. Half the PhDs in biology at MIT are women, and have been for years. Yet, only $26 \%$ of the biology faculty and $39 \%$ of the neuroscience faculty are women. Why? A tantalizing insight comes from a recent study reporting that junior faculty in biology departments across America tend to be hired from postdocs trained in a few elite "feeder labs" (Sheltzer and Smith, 2014). For reasons that are not yet understood, when the PIs of these elite labs are male (but not when they are female), the postdocs are disproportionately male. Since male biology professors far outnumber female professors, it may be that the applicant pool for faculty jobs in biology simply reflects an already-biased postdoc pool.

The most recalcitrant problem impacting the professional lives of women faculty in STEM remains unconscious gender bias (Barres, 2006; Moss-Racusina et al., 2012). Measurable inequities that result from it are easily fixed by data tracking in the university. But what about informal exclusion from important professional interactions? Young women even two generations behind me, including superstars, still report being marginalized by male colleagues as the women reach their late 40s or early 50s. An astonishing example can be seen in biotech start-up companies. An informal study showed that only about $5-8 \%$ of the professors who are co-founders or members of the Scientific Advisory Boards of companies founded in Boston by male professors at Harvard, Harvard Medical School, and MIT are women, and women faculty colleagues report they are not invited to participate (McCook, 2013). These data remind us of what universities were like 20 years ago-or even 50 years ago before Title VII and later Title IX made such behavior illegal. Presumably, this is what universities could look like again if the schools did not continuously address unconscious but powerful discrimination against women.

\section{Conclusion}

The history of women in STEM is contradictory. Society encourages women to be scientists, yet women have had to fight every step of the way to be accepted and treated equitably (Rossiter, 1982, 1995, 2012). A far better under- standing now of the barriers that have disabled them and open discussions of these barriers, and the resulting recruitment of many sympathetic men to their cause, is accelerating progress. Yet, without greater changes in attitudes in society itself, and without the entry of more young women into STEM starting well before college, continuous effort will be required to sustain and to build on the extraordinary gains that have been made.

\section{References}

Bailyn, L. (2011). Putting gender on the table. In Becoming MIT: Moments of Decision, D. Kaiser, ed. (MIT Press, Cambridge, MA), pp. 165-185.

Banaji, M.R., and Greenwald, A.G. (2013). Blind Spot: Hidden Biases of Good People (Delacorte Press, New York).

Barres, B. (2006). Does gender matter? Nature 442, 133-136.

Committee on Women Faculty in the School of Science, MIT (1999). A study on the status of women faculty in science at MIT, The MIT Faculty Newsletter 11. Available at http://web.mit.edu/ fnl/women/women.html, last accessed February 2, 2015.

Committees on Women Faculty in the Schools of Science and Engineering, MIT (2011). A report on the status of women faculty in the schools of science and engineering at MIT, 2011. Available at http://web.mit.edu/faculty/reports/pdf/ women_faculty.pdf, last accessed February 2, 2015.

Hopkins, N. (2007). Diversification of a university faculty, women in the MIT schools of science and engineering. New Engl J Public Policy 22, 119-134.

Hopkins, N. (2011). An account of how the MIT report on women in science came to be written. In Becoming MIT: Moments of Decision, D. Kaiser, ed. (MIT Press, Cambridge, MA), pp. 186-192.

Mason, M.A., Wolfinger, N.H., and Goulden, M. (2013). Do Babies Matter? Gender and Family in the Ivory Tower (Rutgers Press, New Brunswick, NJ).

McCook, A. (2013). Women in biotechnology: barred from the boardroom. Nature 495, 25-27.

Moss-Racusina, C.A., Graham, M.J., and Handelsman, J. (2012). Science faculty's subtle gender biases favor male students. Proc Natl Acad Sci U S A 109, 16474-16479.

Rossiter, M.W. (1982, 1995, 2012). Women Scientists in America, vols. 1, 2, and 3 (The Johns Hopkins University Press, Baltimore, MD).

Sheltzer, J.M., and Smith, J.C. (2014). Elite male faculty in the life sciences employ fewer women. Proc Natl Acad Sci U S A 111, 10107-10112.

Valian, V. (1999). Why So Slow? The Advancement of Women (MIT Press, Cambridge, MA).

Address correspondence to: Nancy Hopkins, PhD Department of Biology MIT 77 Cambridge Avenue Cambridge, MA 02139

E-mail:nhopkins@mit.edu 